\title{
Bovine-associated CNS species resist phagocytosis differently
}

\author{
Silja Åvall-Jääskeläinen', Joanna Koort ${ }^{1}$, Heli Simojoki ${ }^{2}$ and Suvi Taponen ${ }^{2 *}$
}

\begin{abstract}
Background: Coagulase-negative staphylococci (CNS) cause usually subclinical or mild clinical bovine mastitis, which often remains persistent. Symptoms are usually mild, mostly only comprising slight changes in the appearance of milk and possibly slight swelling. However, clinical mastitis with severe signs has also been reported. The reasons for the differences in clinical expression are largely unknown. Macrophages play an important role in the innate immunity of the udder. This study examined phagocytosis and killing by mouse macrophage cells of three CNS species: Staphylococcus chromogenes (15 isolates), Staphylococcus agnetis (6 isolates) and Staphylococcus simulans (15 isolates). Staphylococcus aureus (7 isolates) was also included as a control.

Results: All the studied CNS species were phagocytosed by macrophages, but $\mathrm{S}$. simulans resisted phagocytosis more effectively than the other CNS species. Only S. chromogenes was substantially killed by macrophages. Significant variations between isolates were seen in both phagocytosis and killing by macrophages and were more common in the killing assays. Significant differences between single CNS species and S. aureus were observed in both assays.

Conclusion: This study demonstrated that differences in the phagocytosis and killing of mastitis-causing staphylococci by macrophages exist at both the species and isolate level.
\end{abstract}

\section{Background}

Mastitis is a major disease of dairy cows that is most often caused by bacteria such as staphylococci, streptococci and coliforms. Staphylococcus aureus and coagulase-negative staphylococci (CNS) are isolated in about half of mastitic milk samples in Finland [1] and in many other countries [2-4]. The manifestation of staphylococcal mastitis varies considerably. It is well-known that $S$. aureus is able to cause severe clinical signs, but generally it causes persistent subclinical mastitis. CNS generally cause subclinical or mild clinical mastitis [5], although clinical CNS mastitis with severe signs has also been reported $[4,6]$. Selfclearance of CNS mastitis soon after parturition is commonly expected $[7,8]$, but CNS have been shown to frequently persist in the udder throughout lactation, causing an elevated somatic cell count (SCC) [9-11].

Phagocytic leucocytes form the primary cellular defence of the udder [12]. During lactation, normal milk

\footnotetext{
* Correspondence: suvi.taponen@helsinki.fi

${ }^{2}$ Department of Production Animal Medicine, Faculty of Veterinary Medicine, University of Helsinki, P.O. Box 57, FIN-00014, Helsinki, Finland

Full list of author information is available at the end of the article
}

from a healthy bovine udder contains a small number of leucocytes, usually $<50000 \mathrm{cells} / \mathrm{ml}[9,12]$. These cells, which are first in line to meet possible intruders, are mainly macrophages [12]. The role of these macrophages in either the prevention or induction of inflammation is crucial. Among several other functions, they recognize microorganisms, alert the immune system and initiate an inflammatory reaction (reviewed, for example, in [13]). Only after the initiation of inflammation are polymorphonuclear neutrophils (PMNs) enrolled, which move from the blood into the milk, raising the SCC in the milk to hundreds of thousands or millions cells $/ \mathrm{ml}$. S. aureus is well known for its ability to evade phagocytosis $[14,15]$ and persist in the udder [11]. For example, S. aureus expresses several antiopsonic cell-surface components, including a polysaccharide capsule and surface protein $\mathrm{A}$, which enable the bacteria to efficiently resist phagocytosis. This species also has several mechanisms allowing it to survive within phagocytic cells, including enzymes that neutralize free radicals [14]. CNS are also known to persist in the udder [9-11], which implies that, like $S$. aureus, they have developed means to resist

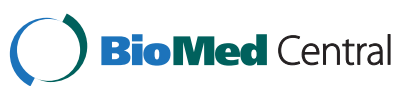


phagocytosis. However, the virulence factors related to the putative ability of CNS from bovine mastitis to resist phagocytosis are still poorly characterized.

Our aim was to investigate the resistance to phagocytosis of the bovine-associated CNS species $S$. chromogenes, S. simulans and S. agnetis, and to examine possible differences in resistance to phagocytosis and killing between these staphylococcal species and isolates. S. chromogenes and S. simulans were selected for study due to their isolation frequencies, and $S$. agnetis to gain information on this recently described species. S. aureus was included as a control. Macrophages were used to represent the primary stage of cell-mediated innate immunity, and a commercial mouse macrophage cell line was selected to achieve stable growth characteristics. Here, we report differences between species and isolates in the phagocytosis and killing of mastitis-causing staphylococci by macrophages.

\section{Methods}

\section{Bacterial isolates and growth conditions}

The 43 Staphylococcus isolates used in this study are listed in Table 1. The isolates were selected on the basis of their clinical properties, and included isolates from clinical or subclinical mastitis as well as from persistent or transient intramammary infection. Almost all isolates originated from different dairy herds, and they were likely to be genetically different. As a reference, isolates from extramammary sites and type strains of Staphylococcus were also included in the study. Staphylococci were routinely grown in Mueller Hinton (LabM, Bury, UK) at $+37^{\circ} \mathrm{C}$. The strains and isolates were maintained at $-80^{\circ} \mathrm{C}$ in Mueller Hinton broth containing $8.7 \%$ (vol/vol) glycerol.

\section{Cell culture}

The murine macrophage cell line J774, derived from BALB/ cN reticulum cell sarcoma (ATCC TIB-67; American Type Culture Collection, Rockville, Md., USA), was maintained at $+37^{\circ} \mathrm{C}$ with $5 \% \mathrm{CO}_{2}$ in growth medium (GM) containing Dulbecco Modified Eagle medium (DMEM High Glucose, GlutaMAX ${ }^{\mathrm{m}}$; Gibco, Grand Island, NY, USA) supplemented with $10 \%$ heat-inactivated foetal bovine serum (Gibco). Cells were maintained as monolayers in $75 \mathrm{~cm}^{2}$ flasks and passaged two or three times weekly by scraping and diluting the cells into fresh DMEM with $5 \%$ foetal bovine serum.

\section{In vitro phagocytosis and killing assay}

The staphylococci to be used in the phagocytosis and killing assays were grown overnight in Mueller Hinton broth. The $\mathrm{OD}_{600 \mathrm{~nm}}$ of the cultures was determined, and the cells were collected by centrifugation, washed once with phosphate-buffered saline (PBS) and resuspended in GM to an approximate concentration of $6 \times 10^{6} \mathrm{col}-$ ony forming units $(\mathrm{CFU}) / \mathrm{ml}$. Cells were divided into aliquots and stored at $-80 \mathrm{C}$ until further use. Before the infection assays, the viability of the frozen Staphylococcus cells was determined by thawing them at $+37^{\circ} \mathrm{C}$ in a water bath for $30 \mathrm{~min}$, followed by suitable dilution in buffered peptone water (LabM, Bury, UK) and plating on Mueller Hinton agar. The number of viable Staphylococcus cells was determined by counting the CFU after overnight incubation (20-23 h).

The in vitro phagocytosis and killing assays were performed essentially as described previously [19], with some modifications. Murine J774 cells were seeded into 24-well microtiter plates (Greiner Bio-One, Frickenhausen, Germany) at a density of $1 \times 10^{5}$ cells per well (volume $800 \mu \mathrm{l})$. After $24 \mathrm{~h}$, these cells were infected with $1 \times 10^{5}$ of Staphylococcus cells (in $50 \mu \mathrm{l}$ volume) derived from frozen aliquots. Before addition to plates, the bacteria were thawed for $30 \mathrm{~min}$ in a water bath at $37^{\circ} \mathrm{C}$ and diluted in fresh GM. The plates were centrifuged shortly after the addition of bacteria (5 min $180 \mathrm{~g} \mathrm{RT}$ ). Thereafter, the plates were incubated for $1 \mathrm{~h}$ at $+37^{\circ} \mathrm{C}$ with $5 \% \mathrm{CO}_{2}$.

After incubation, the treatment of plates differed between phagocytosis and killing assays. In the killing

Table 1 The staphylococcal isolates used in the phagocytosis assay ${ }^{1}$

\begin{tabular}{|c|c|c|c|c|c|c|c|}
\hline \multirow[b]{2}{*}{ Species } & \multicolumn{7}{|c|}{ Source of isolates } \\
\hline & $\begin{array}{l}\text { Clinical } \\
\text { mastitis }\end{array}$ & $\begin{array}{l}\text { Subclinical } \\
\text { mastitis }\end{array}$ & $\begin{array}{l}\text { Persistent subclinical } \\
\text { mastitis }\end{array}$ & $\begin{array}{c}\text { Transient subclinical } \\
\text { mastitis }\end{array}$ & $\begin{array}{l}\text { Extra-mammary } \\
\text { sites }\end{array}$ & $\begin{array}{l}\text { Type } \\
\text { strain }\end{array}$ & $\begin{array}{c}\text { Total } \\
\text { number }\end{array}$ \\
\hline S. chromogenes & 4 & 4 & 2 & 2 & 2 & 1 & 15 \\
\hline S. simulans & 4 & 4 & 2 & 2 & 2 & 1 & 15 \\
\hline S. agnetis & $3^{*}$ & 3 & & & & $(1)^{*}$ & 6 \\
\hline S. aureus & 2 & 4 & & & & 1 & 7 \\
\hline Total number & 13 & 15 & 4 & 4 & 4 & 4 & \\
\hline
\end{tabular}

${ }^{1}$ The isolates from clinical or subclinical mastitis, except for two S. aureus isolates from subclinical mastitis, originate from the data of [16]. Two S. aureus isolates from subclinical mastitis originate from the data of Taponen et al. [17]. The isolates from persistent or transient bovine mastitis originate from the study of Taponen et al. [9] and the isolates from extramammary sites (skin of the udder, teats, perineum, and the milker's hand) originate from the study of Taponen et al. [18].

${ }^{*}$ One of the S. agnetis isolates from clinical mastitis is the S. agnetis type strain DSM $23656^{\top}$. 
assay, the J774 cells were lysed by incubating them in GM with $0.1 \%$ saponin (vol/vol; Merck kGaA, Darmstadt, Germany) for 15 min at $+37^{\circ} \mathrm{C}$ with $5 \% \mathrm{CO}_{2}$. Thereafter, the lysed samples were removed from wells by vigorous pipetting, the wells were washed with PBS and the recovered buffer was combined with the lysate previously recovered from the wells. Aliquots from these samples were plated as described in the viability determination of frozen Staphylococcus cells to count the total number of surviving bacteria in the samples. In the phagocytosis assay, after infection, the extracellular bacteria were recovered by carefully removing the GM from the wells. Thereafter, the wells were washed with PBS by cautious pipetting and the recovered buffer was combined with the GM previously recovered from the wells. To count the extracellular bacteria in these samples, plating was carried out as in the killing assay.

As a reference for both assays, staphylococci were incubated simultaneously in plates without J774 cells, and the wells in these plates were treated as in the phagocytosis assay. The numbers of killed staphylococci were calculated by subtracting the counts of surviving staphylococci from the counts of staphylococci in reference samples. The numbers of phagocytosed staphylococci were calculated by subtracting the counts of extracellular staphylococci from the counts of staphylococci in reference samples. The quantities of killed and phagocytosed staphylococci are presented as percentages of reference sample values. Each value represents the mean of three independent experiments, with two replicates for each sample in a single experiment.

\section{Statistical analysis}

Mean values for the phagocytosis and killing of each of the studied Staphylococcus species and isolates by murine macrophage cell line J774 were calculated. All results are expressed as arithmetic means \pm standard deviation. The studied isolates were grouped on the basis of variables related to the nature of infection (clinical/subclinical) in order to determine whether this isolate attribute has an effect on the phagocytosis or killing of staphylococci by murine J774 macrophages.

The possible effects of staphylococcal species, staphylococcal isolate and the above-mentioned isolate attributes on the phagocytosis and killing of staphylococci by the murine macrophage cell line J774 were examined. The arithmetic means of the three repeated, independent experiments for each isolate were used in the statistical analyses in order to avoid the clustering effect. The independent-samples Kruskal-Wallis test was used to study the possible effects of these factors on phagocytosis, for which the data were not normally distributed. The data for bacterial killing were normally distributed and ANOVA was used to examine the possible effects of these factors on killing. Test results were considered statistically significant if the calculated $p$ values were $<0.05$.

\section{Results}

Phagocytosis of staphylococci by the murine macrophage cell line $\mathbf{J 7 7 4}$

Staphylococci were not resistant to phagocytosis by murine J774 macrophages, since phagocytosis occurred for all the isolates of the four studied Staphylococcus species during the one-hour incubation with these cells (Figure 1). Among all the studied staphylococcal isolates, the mean percentages of phagocytosis varied from $\sim 40 \%$ (S. simulans isolate 116) to $\sim 97 \%$ (S. chromogenes isolate 316). The standard deviation of the mean phagocytosis rates varied from $1.3 \%$ (S. chromogenes isolate 316 ) to $32.8 \%$ (S. simulans isolate 102).

The mean percentage of phagocytosis for S. simulans was $68.4 \% \pm 21.36 \%$, whereas for the other studied species it varied between $83.3 \%$ and $91.0 \%$ (Figure 2A). For all the studied Staphylococcus species, the median percentage of phagocytosis did not significantly differ from the mean values (results not shown). S. simulans was significantly less phagocytosed than S. agnetis $(p=0.014)$ and S. chromogenes $(p<0.001)$. In contrast, no significant difference in phagocytosis was observed between $S$. simulans and $S$. aureus $(p=0.185)$, while $S$. aureus was significantly less phagocytosed than $S$. chromogenes $(p=0.020)$. No differences in phagocytosis were recorded between isolates derived from either subclinical or clinical infections $(p=0.544)$.

Large and statistically significant variation was recorded in the phagocytosis of different $S$. simulans isolates which varied from $39.9 \% \pm 11.4 \%$ to $91.5 \% \pm 3.6 \%$. Such variation between isolates was not observed for the other Staphylococcus species.

\section{Killing of staphylococci by murine macrophage cell line $\mathrm{J774}$}

There was considerable variation between bacterial species in the killing of staphylococci by murine J774 macrophages during the one-hour incubation period (Figure 2B). S. chromogenes was more efficiently killed by murine $\mathrm{J774}$ macrophages than any of the other Staphylococcus species studied. The $p$-values of statistical differences between $S$. chromogenes and S. simulans, S. agnetis or S. aureus were $<0.001,0.048$ and 0.016 , respectively. The mean percentage of killing for S. chromogenes was $25.10 \% \pm 27.41 \%$, but for the other Staphylococcus species the values were negative (Figure $2 \mathrm{~B}$ ). This was most likely due to the multiplication of bacterial cells in the GM during saponin treatment (Åvall-Jääskeläinen et al., unpublished observations).

Substantial differences were detected in the killing of different isolates within a single species for all the studied CNS species. Some of the studied Staphylococcus isolates were not killed at all, whereas others were 

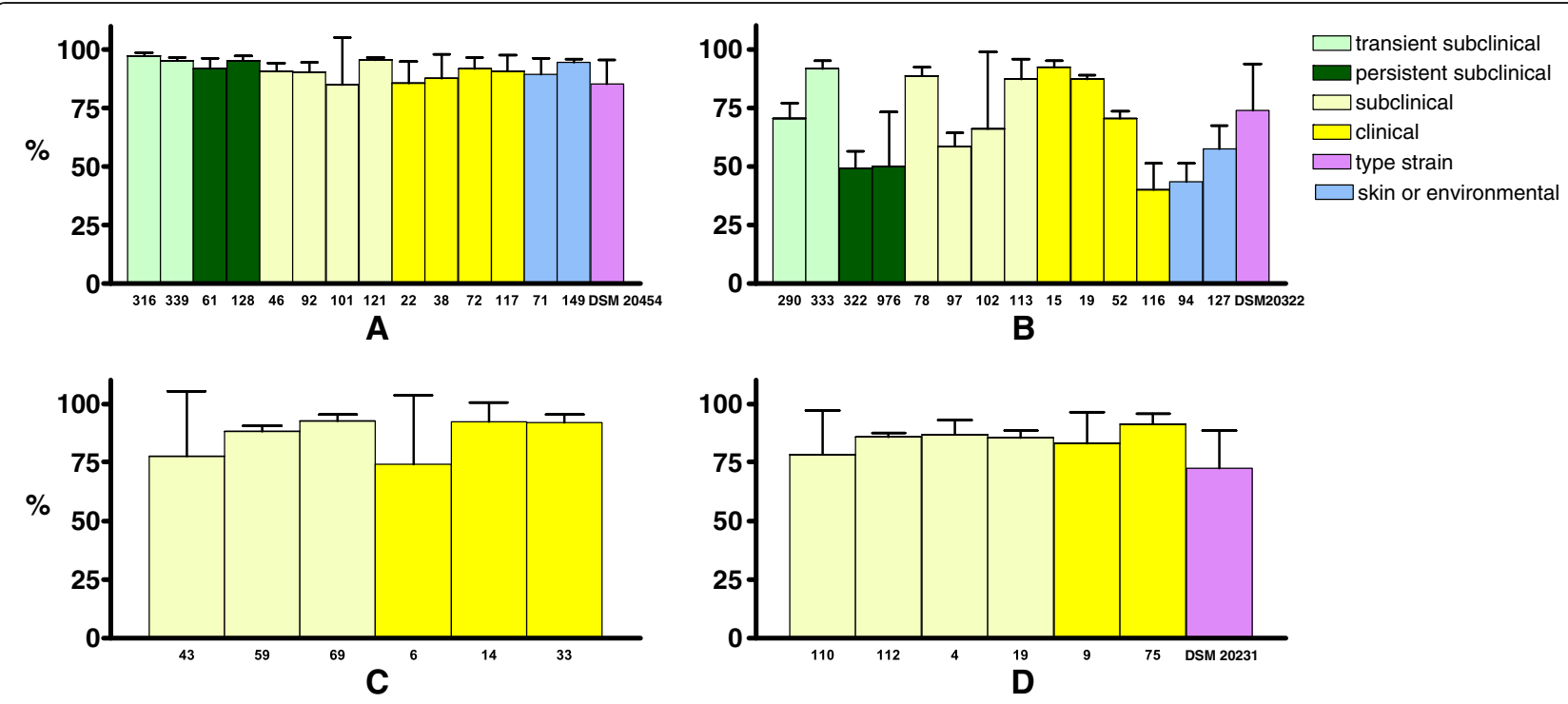

Figure 1 The mean phagocytosis percentages $( \pm S D)$ of S. chromogenes (A), S. simulans (B), S. agnetis (C) and S. aureus (D) isolates by murine $\mathbf{J 7 7 4}$ macrophages. Bars indicate the average result \pm standard deviation of three separate assays, with two replicates of each sample in a single experiment. The origins of the isolates included are marked with different bar colours.

efficiently killed. The maximum mean percentage killing of a single isolate was $60.1 \%$ (S. chromogenes isolate 92 ) (Figure 3). No difference was recorded in the killing of isolates derived from either subclinical or clinical infections $(p=0.363)$.

\section{Discussion}

This study examined the ability of macrophages to phagocytose and kill bovine mastitis-associated strains of S. aureus and the CNS species S. simulans, S. chromogenes and S. agnetis. This is related to the capability of the bacteria to initiate infection, as resistance to macrophages is crucial, especially in the first stages of infection. As references, extramammary isolates and type strains of these staphylococcal species were also included. All the studied species were phagocytosed, although differences were recorded in the efficacy of phagocytosis. S. simulans resisted phagocytosis more than S. chromogenes and S. agnetis. Inside the macrophages, $S$. chromogenes was more efficiently killed than the other Staphylococcus species.

Although the phagocytosis of bovine mastitis-associated S. aureus by PMNs [20-22] and macrophages [23,24] has been extensively studied, the phagocytosis of CNS has earlier received little if any research attention. For this study, we selected CNS species that are not only relevant and frequent, but also differ from each other as a cause of bovine mastitis. Thus, S. chromogenes and S. simulans, species belonging to the few most frequently isolated CNS species in the Nordic countries [4], were chosen. S. chromogenes is suspected to belong to the bovine skin microbiota $[18,25]$, and is also the most commonly isolated CNS species in bovine milk, especially in heifers around calving [26] and in first lactation [16]. S. simulans, also commonly isolated in mastitic milk samples, especially in Nordic countries $[4,16]$, has been reported to have a tendency to cause a stronger inflammatory reaction than other CNS species [16]. S. agnetis, a recently described bovineassociated coagulase-variable species [27], was also included as a new species for which information is still limited. S. agnetis, described by our research group, is frequently isolated from mastitic milk samples, but does not belong to the few most commonly isolated CNS species (Taponen, unpublished results). It is closely related to and was earlier classified as S. hyicus, which has been reported to cause stronger inflammatory reactions than many other CNS species [28]. Few studies have examined the phagocytosis of S. simulans [29-31], and the present study is, to our knowledge, the first examining the phagocytosis of S. chromogenes and S. agnetis.

In this study we used murine macrophages rather than neutrophils, as in the udder they are the first phagocytes of innate immunity and thus have an important role in the early immune response [13]. To ensure repeatability, we used a commercially available cell line rather than freshly isolated cells. To our knowledge, no commercial bovine macrophage cell lines are available. However, the murine macrophage cell line J774 has stable growth characteristics and has been used in numerous bacterial phagocytosis studies $[19,32,33]$. In terms of the innate recognition of bacteria, the differences between murine and bovine macrophages are quite small. For example, the selection of toll-like receptors (TLRs), known to be the most important pattern-recognition receptor family, 


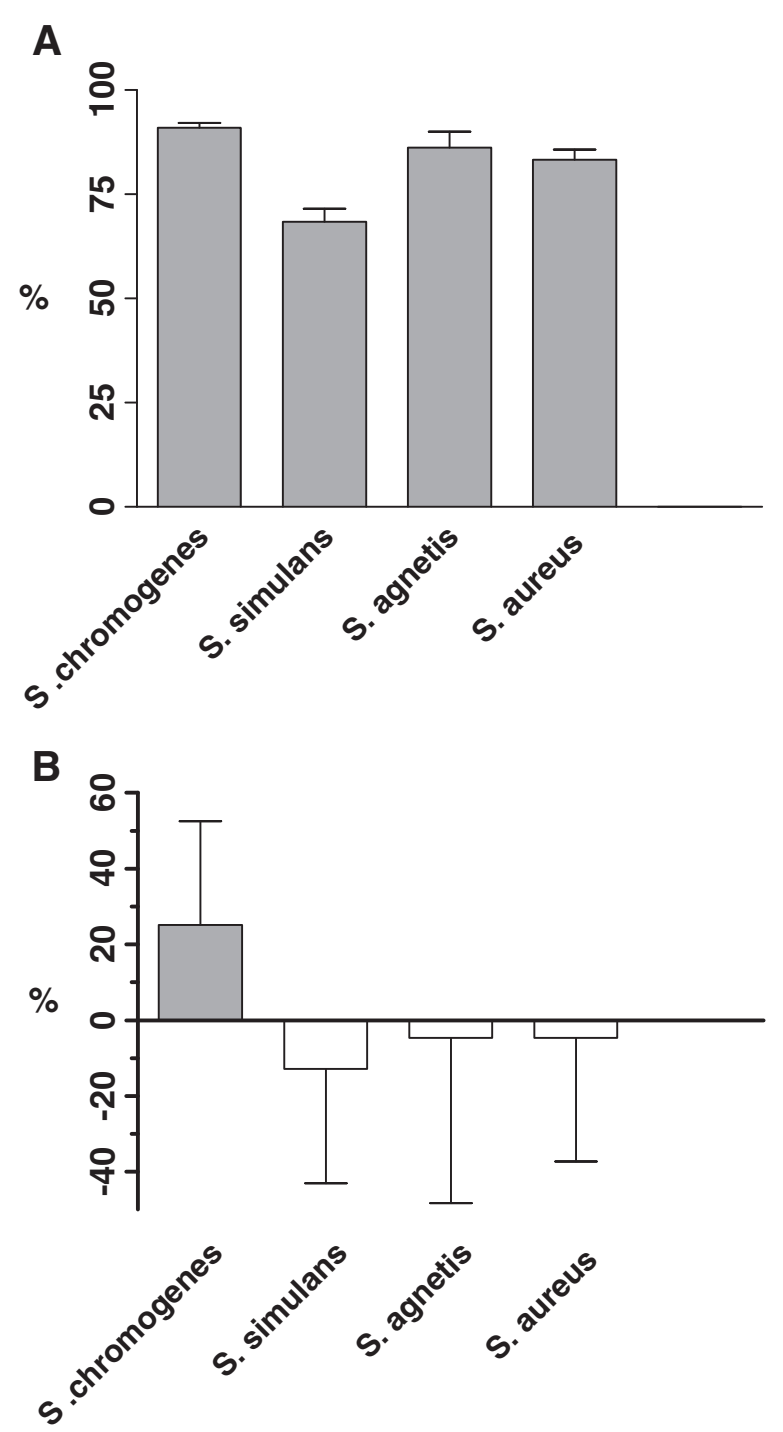

Figure 2 The mean phagocytosis (A) and killing (B) percentages $( \pm$ SD) of S. chromogenes, S. simulans, S. agnetis and S. aureus by murine $\mathbf{J 7 7 4}$ macrophages. S. simulans was less phagocytosed than $S$. agnetis $(p=0.014)$ and $S$. chromogenes $(p<0.001)$. S. aureus was less phagocytosed than $S$. chromogenes $(p=0.020)$. $S$. chromogenes differed from other species and was killed more efficiently $(p<0.05)$. Negative values for killing are due to the growth of staphylococci during saponin treatment.

is similar in macrophages of both species, as mouse macrophages possess all the known cell surface TLRs of cattle macrophages. Murine macrophages can thus be used to evaluate trends and differences in phagocytosis between the different bovine-associated bacterial isolates, keeping in mind that the values for phagocytosis obtained this way are not necessarily exactly the same as would be obtained by using bovine macrophages. When phagocytosis and killing were compared between the CNS species, some significant differences were seen. S. simulans resisted phagocytosis more effectively than the other CNS species studied, and if phagocytosed, also resisted killing by phagocytes as effectively as $S$. agnetis or even S. aureus. S. chromogenes, by comparison, was phagocytosed more easily than S. simulans, and also more efficiently killed by phagocytes than any other studied species. Interestingly, these two species also appear to behave differently as udder pathogens. S. simulans is commonly isolated in milk samples originating from mastitic udders $[4,16,28,34]$. In two field studies, a tendency has been observed for $S$. simulans to cause slightly more clinical signs than other CNS species $[16,34]$, and in an experimentally induced bovine mastitis study it caused a slightly stronger inflammatory response when compared to S. epidermidis [35]. On the other hand, S. chromogenes is known to be commonly isolated in bovine mastitis milk samples, especially from first lactation cows $[11,16,26,36]$, and to colonize the teat and udder skin of heifers before and around calving $[25,37]$. Even though these species are both usually classified as opportunists, molecular data indicate that $S$. simulans may be specifically associated with mastitis, whereas S. chromogenes could be regarded as a species belonging to the bovine skin microbiota [18,37]. This difference is consistent with the observation that $S$. chromogenes in this study was more easily phagocytosed and killed than S. simulans. However, despite their differences, both S. simulans and S. chromogenes commonly persist in the udder, even for an entire lactation, causing an elevated milk SCC $[9,11]$. In experimentally induced mastitis [35], six of eight $S$. simulans mastitis infections remained persistent.

This study was the first to examine the phagocytosis of S. agnetis, which is a newly described coagulase-variable staphylococcal species isolated from subclinical and mild clinical bovine mastitis [27]. In this study it is regarded as coagulase-negative, as only few strains are coagulase-positive and production of coagulase is slow compared to that of S. aureus [27]. Most of the known $S$. agnetis isolates have previously been misidentified as S. hyicus by phenotypic identification methods, as the two species are closely related. Very little is known about the infectivity and virulence of this new species. In this study, S. agnetis was significantly more phagocytosed than S. simulans. However, in the killing assay, the results for $S$. agnetis were similar to those for $S$. simulans and even S. aureus, as these bacteria were not killed by murine macrophages.

S. aureus is commonly regarded to have a special status among mastitis-causing staphylococcal species in terms of the severity of inflammation, virulence, persistence and transmission. Although S. aureus mastitis can be severe and sometimes even toxic, it typically, and possibly after a clinical phase, causes chronic subclinical mastitis associated with a moderate or periodically high 


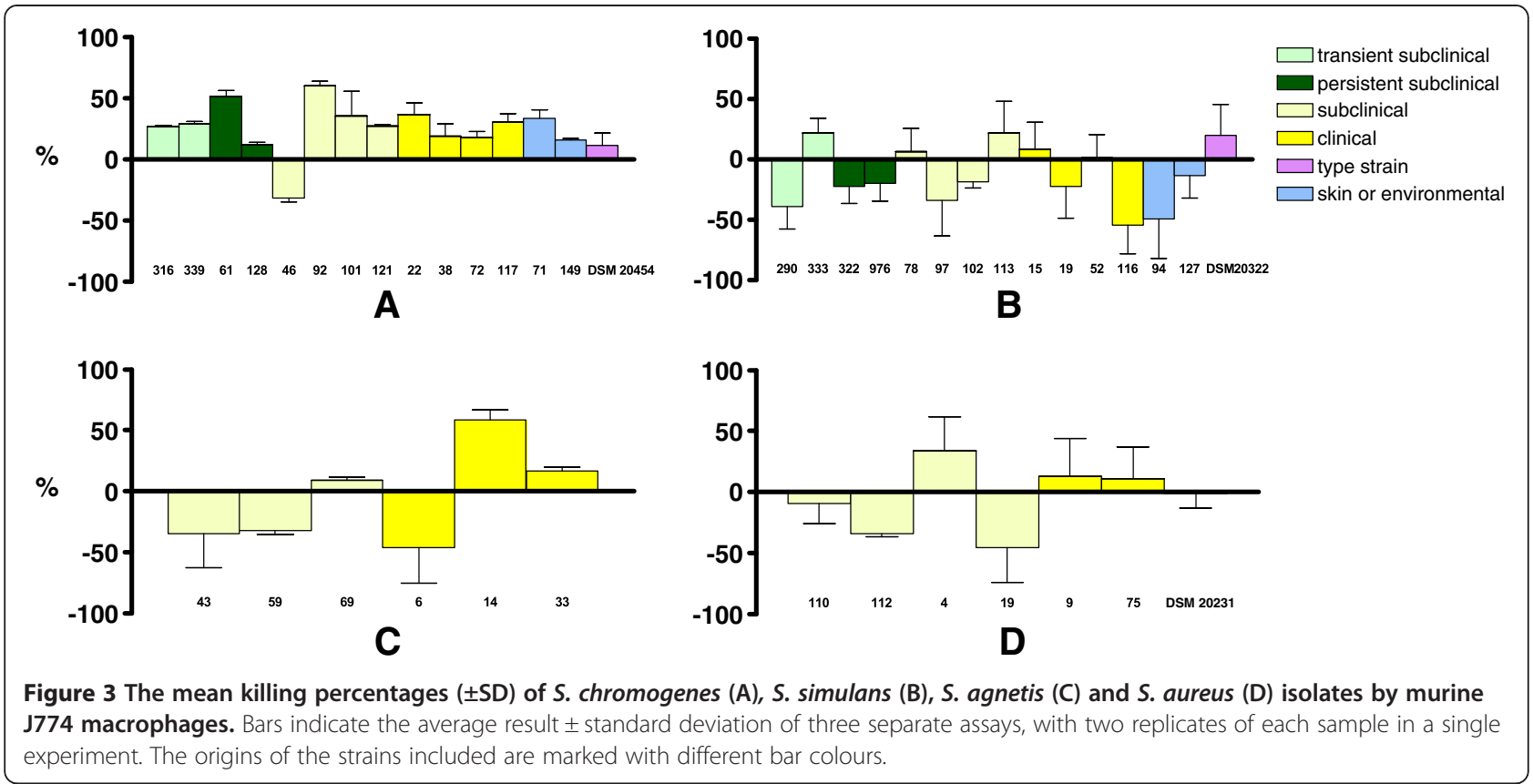

milk SCC. On the contrary, CNS rarely cause clinical mastitis, and the milk SCC in CNS mastitis usually varies from low to moderate, although the SCC may occasionally be high [5]. The mechanisms underlying the differences in the clinical manifestation of $S$. aureus and CNS mastitis are still unknown. In this study, S. aureus did not especially differ from the other Staphylococcus species regarding their phagocytosis or killing by macrophages. On the contrary, S. simulans differed most from the other Staphylococcus species in the phagocytosis assay and $S$. chromogenes in the killing assay.

Isolate differences in phagocytosis were seen in $S$. simulans and in killing for all the studied species. These results are partly the opposite to the study of Aarestrup et al. [20], who found significant differences between $S$. aureus strains in both phagocytosis and killing. However, Aarestrup et al. [20] used neutrophils, which migrate to the udder after the macrophages have initiated an inflammatory response.

In this study, none of the observed differences correlated with the nature of infection (clinical/subclinical). This may, however, be due to the small data sub-sets. Staphylococci can resist phagocytosis and killing in several ways. For example, the capsule and other extracellular polysaccharides are known to influence the efficacy of both phagocytosis and killing [31,38,39]. The Staphylococcus isolates used in this study all have a capsule/extra-cellular polysaccharide layer that can be visualized with Giemsa or Anthony's capsule stain when grown in study conditions (Åvall-Jääskeläinen et al., unpublished observations). However, differences in these structures may exist that affect phagocytosis and/or killing. Other thus far unknown virulence factors can also have an impact on the observed resistance to phagocytosis and/or killing. Further studies are needed to examine these issues.

\section{Conclusions}

S. simulans was significantly less phagocytosed by mouse macrophages than $S$. agnetis or S. chromogenes. In murine macrophages, S. chromogenes was more efficiently killed than any of the other Staphylococcus species studied. However, differences exist between isolates in their resistance to phagocytosis and killing by macrophages. Investigations at the pattern recognition level are needed to identify the mechanisms underlying these differences.

\section{Abbreviations}

CFU: Colony forming unit; CNS: Coagulase-negative staphylococci; GM: Growth medium; PBS: Phosphate-buffered saline;

PMN: Polymorphonuclear neutrophil; SCC: Somatic cell count; TLR: Toll like receptor.

\section{Competing interests}

The authors declare that they have no competing interests.

\section{Authors' contributions}

ST, SÅJ and JK conceived and designed the experiments; SÅJ and JK conducted the laboratory experiments; SÅJ, JK and ST performed the data analysis and ST the statistical analysis; SAJ, JK, ST and HS wrote the manuscript. All authors read and approved the final manuscript.

\section{Acknowledgements}

We thank Juha Jääskeläinen for valuable assistance with the statistical analysis. Taina Lehto, Ulla Viitanen and Anja Osola are acknowledged for their excellent technical laboratory assistance. We also thank Tiina Salomäki for providing cell line ATCC TIB-67. This work was supported by the Mercedes Zachariassen Foundation, and was performed in the Centre of Excellence on Microbial Food Safety Research, Academy of Finland. 


\section{Author details}

'Department of Veterinary Biosciences, Division of Microbiology and Epidemiology, University of Helsinki, P.O. Box 66, FIN-00014, Helsinki, Finland. ${ }^{2}$ Department of Production Animal Medicine, Faculty of Veterinary Medicine, University of Helsinki, P.O. Box 57, FIN-00014, Helsinki, Finland.

Received: 2 May 2013 Accepted: 4 November 2013

Published: 11 November 2013

\section{References}

1. Koivula M, Pitkälä A, Pyörälä S, Mäntysaari EA: Distribution of bacteria and seasonal and regional effects in a new database for mastitis pathogens in Finland. Acta Agric Scand Sect A-Anim Sci 2007, 57:89-96.

2. Sampimon O, Barkema HW, Berends I, Sol J, Lam T: Prevalence of intramammary infection in Dutch dairy herds. J Dairy Res 2009, 76:129-136.

3. Schukken YH, González RN, Tikofsky LL, Schulte HF, Santisteban CG, Welcome FL, Bennett GJ, Zurakowski MJ, Zadoks RN: CNS mastitis: nothing to worry about? Vet Microbiol 2009, 134:9-14.

4. Waage S, Mørk T, Røros A, Aasland D, Hunshamar A, Ødegaard SA: Bacteria associated with clinical mastitis in dairy heifers. J Dairy Sci 1999, 82:712-719.

5. Taponen S, Pyörälä S: Coagulase-negative staphylococci as cause of bovine mastitis- not so different from Staphylococcus aureus? Vet Microbiol 2009, 134:29-36.

6. Bleul U, Sacher K, Corti S, Braun U: Clinical findings in $\mathbf{5 6}$ cows with toxic mastitis. Vet Rec 2006, 159:677-679.

7. McDougall S: Efficacy of two antibiotic treatments in curing clinical and subclinical mastitis in lactating dairy cows. N Z Vet J 1998, 46:226-232.

8. Wilson DJ, Gonzalez RN, Case KL, Garrison LL, Gröhn YT: Comparison of seven antibiotic treatments with no treatment for bacteriological efficacy against bovine mastitis pathogens. J Dairy Sci 1999, 82:1664-1670.

9. Taponen S, Koort J, Björkroth J, Saloniemi H, Pyörälä S: Bovine intramammary infections caused by coagulase-negative staphylococci may persist throughout lactation according to amplified fragment length polymorphism-based analysis. J Dairy Sci 2007, 90:3301-3307.

10. Supré K, Haesebrouck F, Zadoks RN, Vaneechoutte M, Piepers S, De Vliegher S: Some coagulase-negative Staphylococcus species affect udder health more than others. J Dairy Sci 2011, 94:2329-2340.

11. Mørk T, Jørgensen HJ, Sunde M, Kvitle B, Sviland S, Waage S, Tollersrud T: Persistence of staphylococcal species and genotypes in the bovine udder. Vet Microbiol 2012, 159:171-180.

12. Rainard P, Riollet C: Innate immunity of the bovine mammary gland. Vet Res 2006, 37:369-400

13. Mosser DM, Edwards JP: Exploring the full spectrum of macrophage activation. Nat Rev Immunol 2008, 8:958-969.

14. Foster TJ: Immune evasion by staphylococci. Nat Rev Microbiol 2005, 3:948-958

15. Kraus D, Peschel A: Staphylococcus aureus evasion of innate antimicrobial defense. Future Microbiol 2008, 3:437-451.

16. Taponen S, Simojoki H, Haveri M, Larsen HD, Pyörälä S: Clinical characteristics and persistence of bovine mastitis caused by different species of coagulase-negative staphylococci identified with API or AFLP. Vet Microbiol 2006, 115:199-207.

17. Taponen S, Jantunen A, Pyörälä E, Pyörälä S: Efficacy of targeted 5-day combined parenteral and intramammary treatment of clinical mastitis caused by penicillin-susceptible or penicillin-resistant Staphylococcus aureus. Acta Vet Scand 2003, 44:53-62

18. Taponen S, Björkroth J, Pyörälä S: Coagulase-negative staphylococc isolated from bovine extramammary sites and intramammary infections in a single dairy herd. J Dairy Res 2008, 75:422-429.

19. Meyer S, Shin H, Cornelis GR: Capnocytophaga canimorsus resists phagocytosis by macrophages and blocks the ability of macrophages to kill other bacteria. Immunobiology 2008, 213:805-814.

20. Aarestrup FM, Scott NL, Sordillo LM: Ability of Staphylococcus aureus coagulase genotypes to resist neutrophil bactericidal activity and phagocytosis. Infect Immun 1994, 62:5679-5682.

21. Barrio MB, Rainard P, Poutrel B: Milk complement and the opsonophagocytosis and killing of Staphylococcus aureus mastitis isolates by bovine neutrophils. Microb Pathog 2003, 34:1-9.

22. Sutra $L$, Rainard P, Poutrel B: Phagocytosis of mastitis isolates of Staphylococcus aureus and expression of type 5 capsular polysaccharide are influenced by growth in the presence of milk. J Clin Microbio/ 1990, 28:2253-2258

23. Mullan NA, Carter EA, Nguyen KA: Phagocytic and bactericidal properties of bovine macrophages from non-lactating mammary glands. Res $\mathrm{Vet} S \mathrm{C}$ 1985, 38:160-166.

24. Zhen YH, Jin $\sqcup$, Guo J, Li XY, Li Z, Fang R, Xu YP: Characterization of specific egg yolk immunoglobulin (lgY) against mastitis-causing Staphylococcus aureus. J App/ Microbiol 2008, 105:1529-1535.

25. De Vliegher S, Laevens H, Devriese LA, Opsomer G, Leroy JL, Barkema HW, de Kruif A: Prepartum teat apex colonization with Staphylococcus chromogenes in dairy heifers is associated with low somatic cell count in early lactation. Vet Microbiol 2003, 92:245-252

26. Rajala-Schultz P, Smith K, Hogan J, Love B: Antimicrobial susceptibility of mastitis pathogens from first lactation and older cows. Vet Microbiol 2004, 102:33-42.

27. Taponen S, Supré K, Piessens V, Van Coillie E, De Vliegher S, Koort JM: Staphylococcus agnetis sp. nov., a coagulase-variable species from bovine subclinical and mild clinical mastitis. Int J Syst Evol Microbiol 2012, 62:61-65.

28. Myllys V: Staphylococci in heifer mastitis before and after parturition. J Dairy Res 1995, 62:51-60.

29. Anderson JC, Wilson CD: Encapsulated, coagulase-negative strain of Staphylococcus simulans. Infect Immun 1981, 33:304-308.

30. Anderson JC, Williams MR: The contribution of a capsule to survival of staphylococci within bovine neutrophils. J Med Microbiol 1985, 20:317-323.

31. Ohshima Y, Schumacher-Perdreau F, Peters G, Quie PG, Pulverer G Antiphagocytic effect of the capsule of Staphylococcus simulans. Infect Immun 1990, 58:1350-1354

32. Qiu H, KuoLee R, Harris G, Van Rooijen N, Patel GB, Chen W: Role of macrophages in early host resistance to respiratory Acinetobacter baumannii infection. PLoS One 2012, 7:e40019.

33. Toyooka K, Takai S, Kirikae T: Rhodococcus equi can survive a phagolysosomal environment in macrophages by suppressing acidification of the phagolysosome. J Med Microbiol 2005, 54:1007-1015.

34. Jarp J: Classification of coagulase-negative staphylococci isolated from bovine clinical and subclinical mastitis. Vet Microbiol 1991, 27:151-158.

35. Simojoki H, Salomäki T, Taponen S, livanainen A, Pyörälä S: Innate immune response in experimentally induced bovine intramammary infection with Staphylococcus simulans and S. epidermidis. Vet Res 2011, 42:49.

36. Thorberg BM, Danielsson-Tham ML, Emanuelson U, Persson Waller K: Bovine subclinical mastitis caused by different types of coagulase-negative staphylococci. J Dairy Sci 2009, 92:4962-4970.

37. White DG, Harmon RJ, Matos JE, Langlois BE: Isolation and identification of coagulase-negative Staphylococcus species from bovine body sites and streak canals of nulliparous heifers. J Dairy Sci 1989, 72:1886-1892.

38. Nanra JS, Buitrago SM, Crawford S, Ng J, Fink PS, Hawkins J, Scully IL, McNeil LK, Aste-Amézaga JM, Cooper D, Jansen KU, Anderson AS: Capsular polysaccharides are an important immune evasion mechanism for Staphylococcus aureus. Hum Vaccin Immunother 2012, 9:480-487.

39. Spiliopoulou Al, Krevvata MI, Kolonitsiou F, Harris LG, Wilkinson TS, Davies AP, Dimitracopoulos GO, Karamanos NK, Mack D, Anastassiou ED: An extracellular Staphylococcus epidermidis polysaccharide: relation to polysaccharide intercellular adhesin and its implication in phagocytosis BMC Microbiol 2012, 12:76.

doi:10.1186/1746-6148-9-227

Cite this article as: Åvall-Jääskeläinen et al:: Bovine-associated CNS species resist phagocytosis differently. BMC Veterinary Research 2013 9:227. 